\title{
Gender Representation of the Anti-Globalisation Movement in the Alternative Media
}

\author{
MARTA KOLÁŘOVÁ* \\ Institute of Sociology, Academy of Sciences of the Czech Republic, Prague
}

\begin{abstract}
The article focuses on the visual representation of men and women in the anti-globalisation movement in the alternative media. Two specific occasions are addressed: the demonstrations in Prague (2000) and Genoa (2001). Semiotic and content analyses are applied in a comparison of British and Czech alternative magazines. A brief history of the anti-globalisation movement, theories of alternative media, and gender representation in media is provided. The research shows that the anti-globalisation struggle is represented as gendered, and traditional gender roles are reproduced in the alternative media. Fewer women than men are represented in the media coverage, and women and men are shown performing different activities. Women are mostly associated with non-violent and creative actions, while men are more often depicted as fighters. Violent protest is considered more effective and important; male tactics are the norm. The British and Czech media do not differ significantly in terms of how men and women at the demonstrations or in the movement are represented.

Sociologický časopis/Czech Sociological Review, 2004, Vol. 40, No. 6: 851-868
\end{abstract}

\section{Introduction}

The typical image of the anti-globalisation struggle is usually of masked activists fighting the police or smashing the windows of McDonalds. The protesters are usually men; the media tend not to show women. Yet, is the anti-globalisation movement only a man's affair? That is the picture the mainstream media suggest. I would like to examine whether the alternative media represent the movement any differently.

In this article I will examine the issue of how men and women in the anti-globalisation movement are represented in the alternative media using semiotic and content analyses applied to a comparison of British and Czech alternative magazines. Two specific occasions are addressed: the demonstrations against the meeting of the International Monetary Fund (IMF) and the World Bank in Prague in 2000 and against the G8 meeting in Genoa 2001. I am particularly interested in how

\footnotetext{
* Direct all correspondence to: Marta Kolářová, Department of Gender and Sociology, Institute of Sociology, Academy of Sciences of the Czech Republic, Jilská 1, 11000 Prague 1, e-mail: marta.kolarova@soc.cas.cz
}

(C) Sociologický ústav AV ČR, Praha 2004 
women and men are represented in these cases, as I participated in these protests, and thus I am able to compare their representation in the media with my own knowledge of what really took place.

In this analysis I want to take a closer look at the gender aspect of the antiglobalisation movement because it has not yet been closely examined, and because, overall, the gender analysis of social protest is underdeveloped [West and Blumberg 1990: 7]. ${ }^{1}$ In doing so, I will first outline the theoretical framework, drawing on theories of gender and representation and theories of the alternative media, and I will then describe the methods I have used. I will proceed to analyse how men and women are represented in the media, what meanings they are associated with, and how these representations relate to reality. In this article I will argue that the alternative media represent the anti-globalisation struggle as gendered and reproduce stereotypical images of men and women.

\section{The anti-globalisation movement and gender}

In order to specify what the anti-globalisation movement is the term itself merits discussion. 'Anti-globalisation' is a media label, but the movement refers to itself as 'anti-capitalist' [Notes from Nowhere 2003] because it is not protesting against globalisation (it is itself globalised) but rather against capitalism. It has also been referred to as 'anti-corporate' [Starr 2000]. ${ }^{2}$

The anti-globalisation movement arose in the 1990s. The demonstrations against the WTO in Seattle in 1999 or the Zapatista uprising in Chiapas, Mexico, in 1994 are most commonly seen as its origin. The anti-globalisation movement is made up of a variety of movements throughout the world: worker, student, environmentalist, human rights, anarchist, socialist, feminist, and various local movements (for example, landless people in Brazil). As a whole, they struggle against neo-liberal capitalism, trans-national corporations, and the policies of institutions such as the WTO, the World Bank and the IMF. The history of the movement has been marked by demonstrations against the meetings of these institutions. Among the most important demonstrations were those in Seattle (1999), Prague (2000), Quebec, Gothenburg, Genoa (2001), Barcelona (2002), and Cancún (2003). Recently the movement has also been addressing the issue of war.

Starr [2000] notes that the movement is multi-issue and also incorporates gender. Mohanty [2003], however, suggests that the movement does not focus on gender issues, instead reflecting inequalities based mostly on class and ethnicity, but

\footnotetext{
1 Especially in Czech academia, where no gender analysis is included even in the sole work on significant theories of social movements [Znebejánek 1997].

2 I would prefer to use the term 'anti-capitalist', because of its content, but I have chosen to use the term 'anti-globalisation' in order to be clear that I am referring to the anti-capitalist movement in its most recent form, since the 1990s.
} 


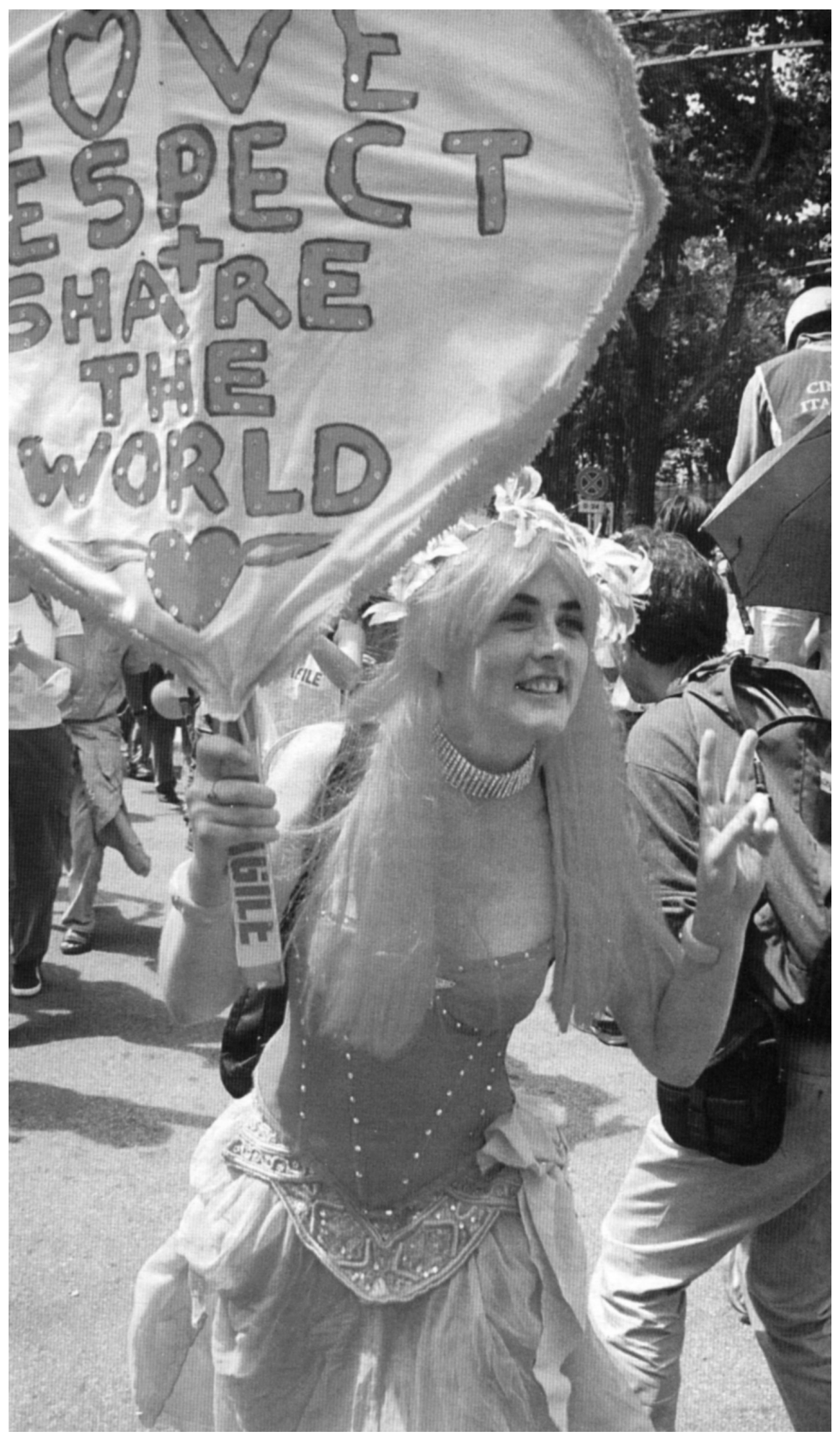

Girl with a Heart (Genoa), from 'On Fire' 


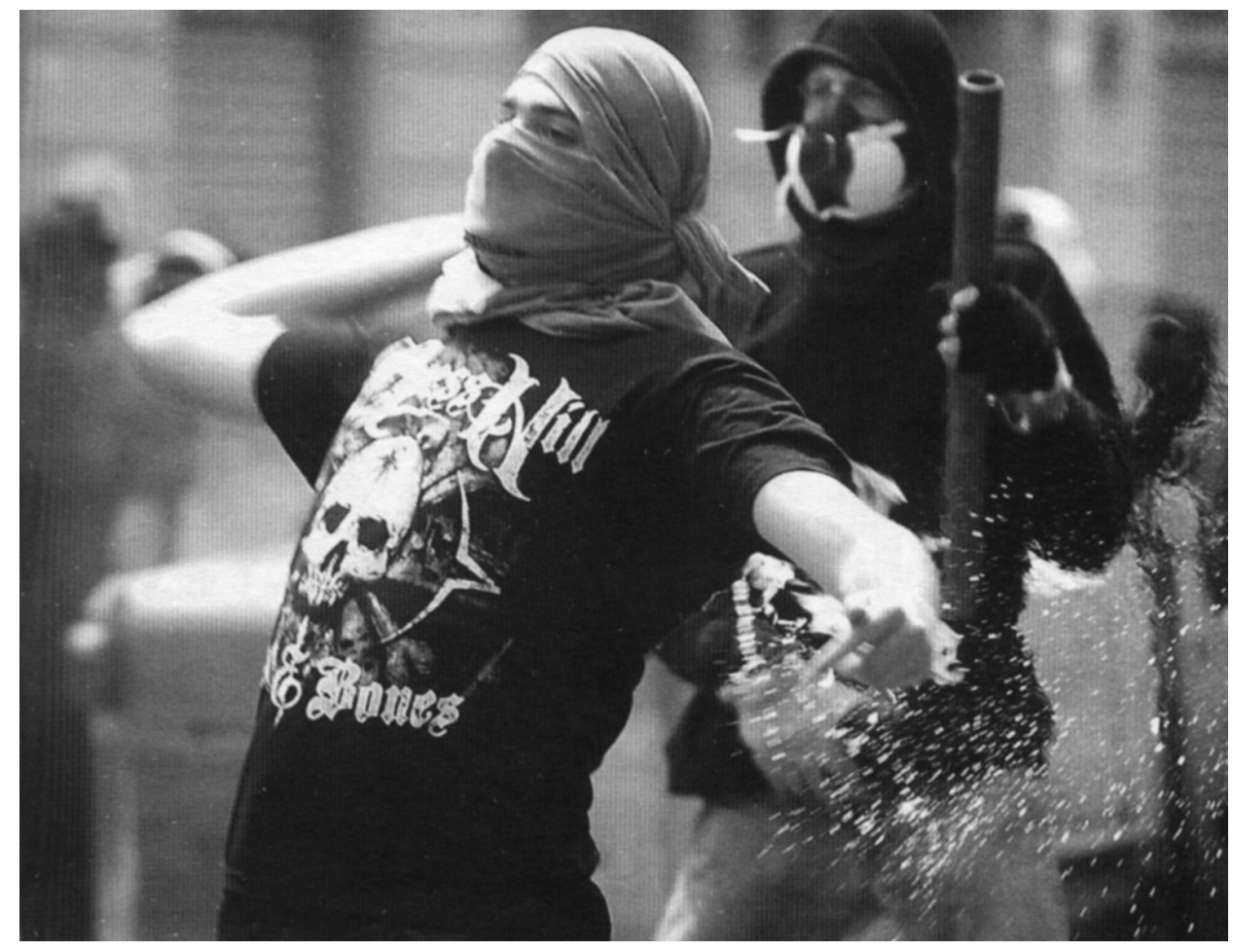

Men Throwing Rocks (Genoa), from 'On Fire' 
that women and feminists participate in it, ${ }^{3}$ and she speaks of the "implicit masculinisation of the discourses of anti-globalisation movements" [Mohanty 2003: 529]. Waterman [2001] claims that there are not many women or feminists participating in the movement.

\section{The alternative media (and gender)}

In the context of social movements it is also important to study the alternative media. ${ }^{4}$ The editors of alternative publications are not satisfied with the representation of protest, minority groups, and certain issues in the mainstream media and want to present their own views, express opposition, and build networks of solidarity. The alternative media I analysed are non-commercial, small-scale publications independent of political parties and with a more democratic organisational base and an active reading public [Atton 2002; Downing 2001]

Both Atton [2002] and Downing [2001] suggest that the alternative media are radical to different degrees and in particular aspects, they put forth the notion of 'mixed radicalism'. The media often neglect "women's issues in labour and ethnic struggles or of racism in women's movement debates" [Downing 2001: 32], because social movements are shaped within capitalist, racist, and patriarchal culture.

\section{Representation and gender}

Feminist media critics in the 1970s claimed that the media in general presented distorted and unrealistic images of women or excluded women entirely. The mass media were perceived as an instrument for the transmission of stereotypical patriarchal values about women and femininity. Such media were considered 'bad'. There was an effort to improve the content of representation and to present realistic and positive images of women, and feminists tried to produce their own 'good' media [Geraghty 1996; Hermes 1997; Zoonen 1996].

Complaints about the lack of realism in the media raised questions about the media and reality. Criticism was based on the assumption that the media provide a realistic representation of the world. But this representation is always constructed. The media do not simply reflect the world, they interpret it from various points of view. Representation presents only the partial truth of a particular social group [Allen 1992: 37; Macdonald 1995: 3].

\footnotetext{
${ }^{3}$ See 'Desire for Change: Women on the Frontline of Global Resistance' [2001] which presents interviews with several women from various local movements around the world.

${ }^{4}$ Sometimes called the 'radical' media [Downing 2001]. By 'radical' the author means that these media are concerned with social change; 'alternative' is more general [Atton 2002: 9].
} 
Furthermore, there is the question of who should decide which images of women are 'accurate' and whose version of reality should be given priority. Feminists often ignored the viewpoints of women of colour, lesbian women, and others. Pollock [1987] suggested that instead of evaluating the representation of women as wrong we should view the woman as a signifier, examine her in relation to other signifiers, and compare the meanings associated with women with those associated with men.

\section{Method of research}

A full analysis of the alternative media's representation of gender in the anti-globalisation movement would involve a broad range of issues. Therefore, I have focused on the movement in the global north and in the print media only. Although the readers and the production of the alternative media should also be studied from a gender perspective, there is no space for that here. Therefore, the analysis focuses on the message and on social modality [Rose 2001]. The comparison of British and Czech alternative media uses two examples from each country: the British magazines 'SchNEWS' (published by Justice?, a direct action collective in Brighton) and 'Do or Die' (by Earth First! groups), ${ }^{5}$ and the Czech magazines 'A-kontra' (published by the Czechoslovak Anarchist Federation, usually 6 to 10 issues per year) and 'Svobodná práce' (Free Labour, published periodically by the Federation of Social Anarchists). I also analysed two books: 'We Are Everywhere: The Irresistible Rise of Global Anti-Capitalism' (a history of the actions of the anti-globalisation movement, edited by a collective of activists, mostly from the UK and the USA) and 'On Fire: The Battle of Genoa and the Anti-Globalisation Movement' (articles from various activists, mostly from the UK).

In the analysis I focus on visual images, while also considering the accompanying texts that emphasise the meaning of the images, because the visual is an important component in how femininity and masculinity are defined [Betterton 1987]. The study of representation in photography raises questions of realism, as photography is generally considered a tool for the objective depiction of reality, and yet all events in actuality are interpreted and images constructed from a specific viewpoint [Hall 1997: 19; King 1992: 131].

My use of content analysis suitable for the examination of a large number of images and applied to the specific examples of two demonstrations (Prague and Genoa) made it possible to arrive at some generalisations about gender representation with regard to all demonstrations, but we must nonetheless be cautious about generalising here, as the tactics of the movement differ in time and space.

\footnotetext{
${ }^{5}$ I needed to examine past issues but was unable to obtain them from the British magazines other than 'SchNEWS' and 'Do or Die', which were available as yearbook compilations for previous years. For a description of these publications see Atton [2002].
} 
I worked with nine categories in the analysis: gender, age, group size, degree of nudity/dress, colour of clothing, role of those depicted, physical surroundings, type of activity and police presence. ${ }^{6}$ I examined 169 images, 71 from Prague and 98 from Genoa.

Although content analysis is an objective method, I had to make some interpretations about situations in the photographs, for example the gender of masked activists and the colour of clothing worn by activists, because almost all the images were in black and white. My familiarity with the protests may have helped me because I know the real colour of the clothes.

I also conducted a more detailed, semiotic analysis of some of the images. I applied an inter-textual reading of the images, looking here at the meanings of certain images in relation to the meanings of other images in the context of broader cultural and social systems [Allen 1992: 34; Rose 2001: 88]. I analysed the images of women and compared them with how men are depicted. I also looked at how the various images are related to each other and suggested meanings associated with them.

\section{Gender representation in demonstrations in terms of numbers}

The content analysis showed that many more men than women are depicted in the media images. There are 100 photographs (59\%) in which only men are depicted (including photographs with police officers 7 ) and 9 photographs $(5 \%)$ in which only women are represented. In 31 images $(18 \%)$ there are mixed groups with both sexes, so women are represented together with men more often than alone. ${ }^{8}$

There is little representation of women in each analysed source. A comparison shows that in Czech anarchist magazines photographs of women constitute only around 10\% of all images, whereas in British magazines it is slightly less, at $3 \%$ ('SchNEWS') and 6\% ('Do or Die'). The Czech 'A-kontra' has a small percentage of pictures with men only - 37\% - while the British 'Do or Die' has the largest at $64 \%$. I expected the results to be the opposite, as the Czech movement appears to be much more male-dominated than the British. ${ }^{9}$ The highest proportion of images with

\footnotetext{
${ }^{6}$ In some images there are indexical signs of the police presence (tear gas, water); I have not included these photographs in my analysis.

7 Riot police are usually men. There were only two women among them in Prague (MFDnes, 1 October 2000). I assume the case was similar in Genoa.

8 There are more women represented in Prague (10\% of the images from the demonstrations in Prague) than in Genoa (only 2 images are women-only). The fact that women are more represented in Prague may have been because more women participated there, or because the media found them more interesting; the fact that women are represented less in Genoa could be the result of the particular choice of source - 'On Fire' focuses more on violent protest.

9 Conversely, after the protests in Prague the Czech public reacted with horror to the violence, so the alternative media may have presented the situation as more peaceful, and some-
} 
women-only images (20\%) and together the lowest percentage of men-only images $(30 \%)$ are in 'We Are Everywhere'. ${ }^{10}$ This may be deliberate, because the book is distributed beyond alternative circles, and it may be understood as an advertisement for non-violent protest within the movement. The lowest representation of women-only images is in 'On Fire' (2\%). The editors claim that this book is about militant protest, ${ }^{11}$ so it could hardly be accused of not presenting other types of protests. From the images at least we can see that the editors in the alternative media consider a subject worth making a book about is confrontational protest.

When group size is combined with gender, women are represented usually in smaller groups (up to three people) or alone. I expected that women would be depicted alone and men in larger groups, but this hypothesis has not been verified, because men are also represented alone.

In the examined images mostly young people are represented. If there are older people, they are depicted in larger, mixed groups, usually marching or with their hands raised (or not as demonstrators but as delegates to conferences), and not fighting. Older women do not seem to be represented.

Women are generally shown with less clothing than men. In addition to one case of nudity that is depicted - a man in Prague - there are also seven people depicted as partially naked, ${ }^{12}$ six of whom were women in carnival costumes and most of whom were in Prague. One man depicted with some exposed parts of the body was the activist killed in Genoa, who was examined by police in the street. In about one-third of the images the activists were normally dressed, but in $57 \%$ of photographs there were people wearing some form of protection (balaclava, gas mask, helmet, scarf on face, white overall with pads) and the majority of them appear to be men. I found only three women depicted with protective clothing, one in white overalls and two with their faces under black masks. These women were depicted in mixed groups, and they were the only women there.

I also examined the colour of the activists' clothing, because colour has a symbolic meaning here. In the anti-globalisation movement there is a Black Bloc known for violent tactics and damaging property, a Pink (or pink/silver) Bloc that uses creative protest with music and dance, and there are the White Overalls who come protected and well prepared to fight with police. The colour dimension is interesting from the perspective of gender, as from birth men are traditionally associated with

thing associated with women (see next section). But this is true for 'A-kontra' only and not 'Free Labour'.

${ }^{10}$ But we should also take into account the very small number of images from Prague and Genoa in this book (ten).

11 Where more men than women participate (see next sections).

12 Legs, whole arms, midriffs - these parts of the body were apparently bared to be attractive (to the media). I have not counted naked arms in T-shirts or legs in shorts, because the demonstration took place who come protected and well prepared to a hot summer day in Genoa. 


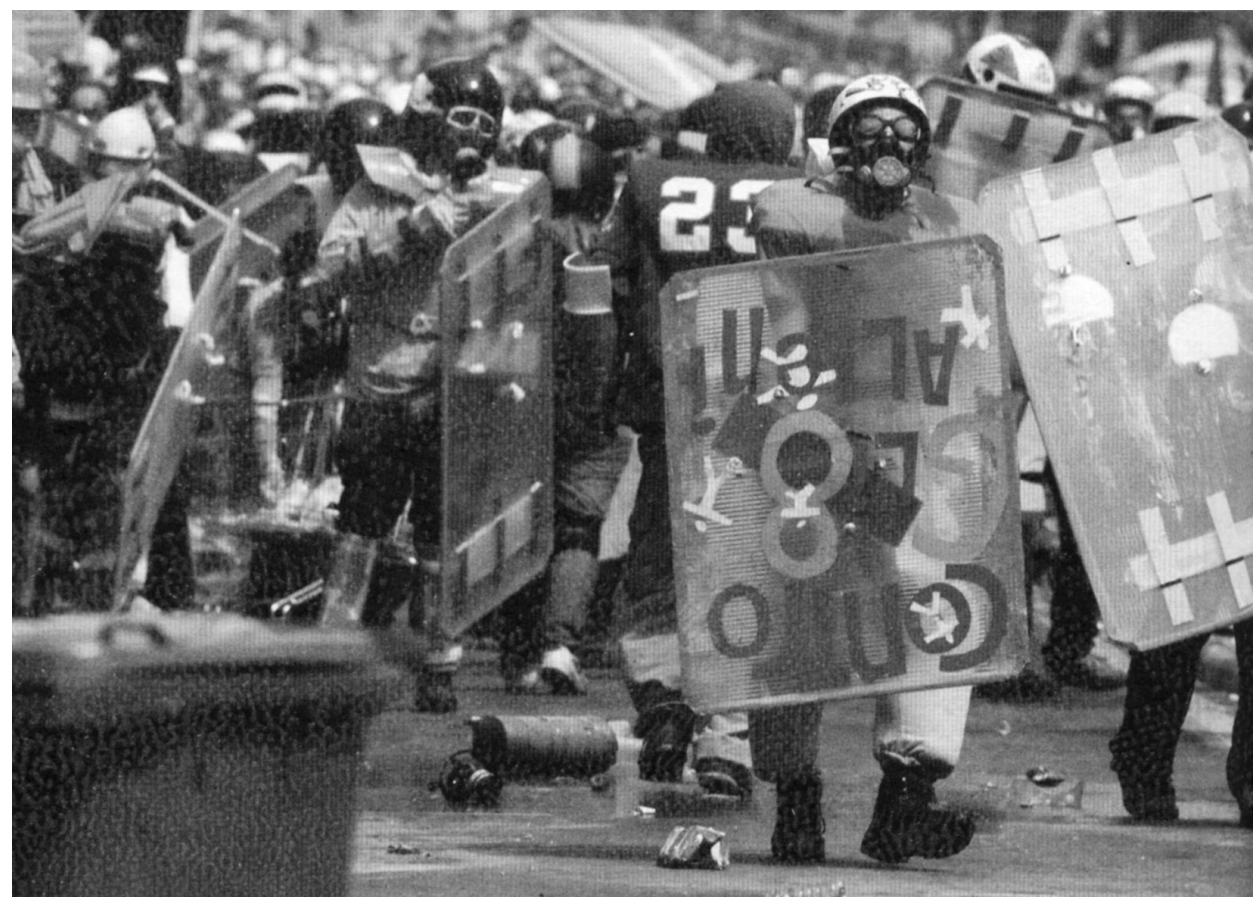

Men in Protection (Genoa), from 'On Fire' 


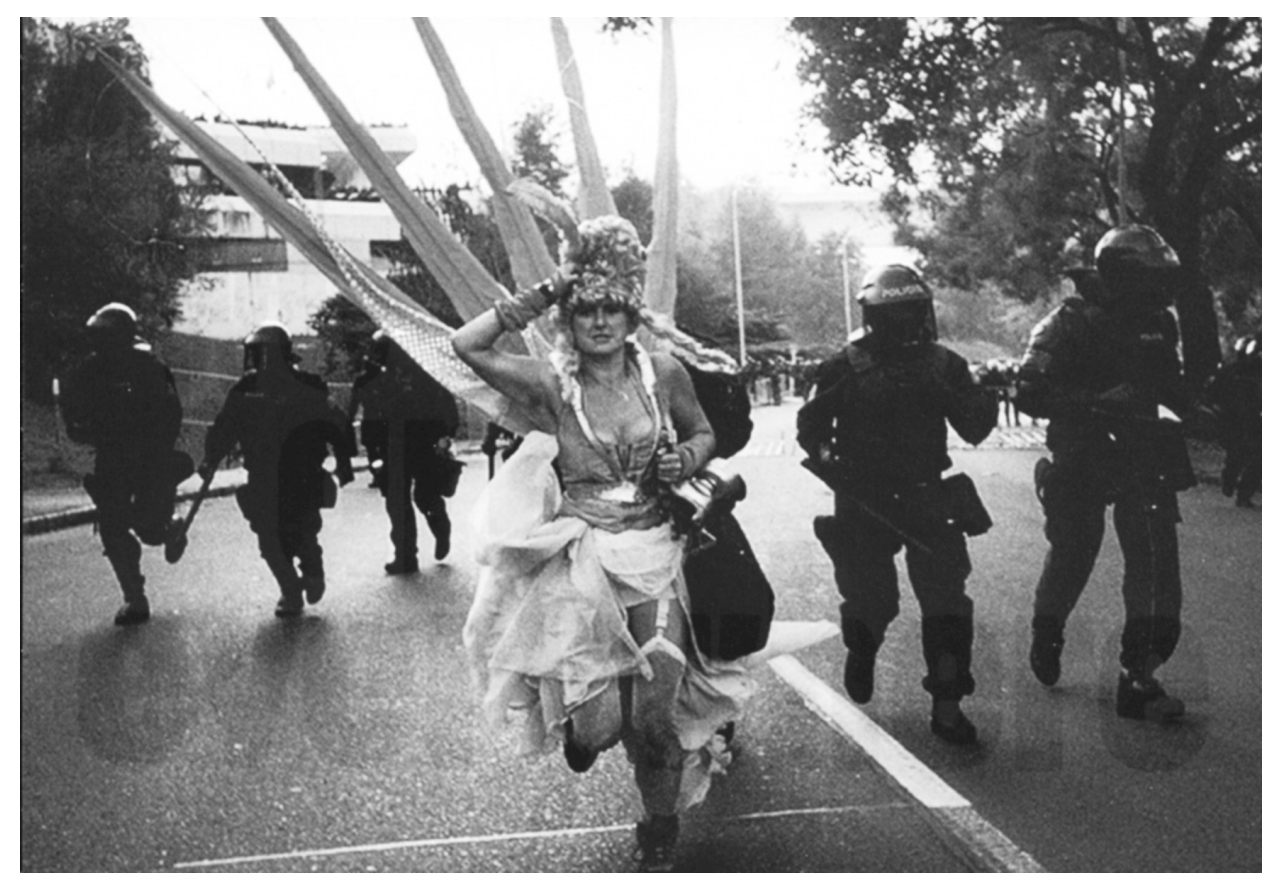

Frivolity on the Run (Prague), reprinted by permission of the editors of 'We Are Everywhere'. Photograph: Meyer/Tendance Floue. 
the colour blue and women with pink. The photographs include a total six images with people dressed in pink and all of them are of women. Almost all women activists are depicted in pink costumes that reveal some parts of the body. One half of all the images of people portray the demonstrators dressed in black, and the majority of them show men. There are more depictions of men in black clothes from the demonstrations in Genoa. ${ }^{13}$ There are fewer images of people in white overalls (8), and these activists were mostly men, except in one photograph with a mixed group. In the rest of the images there are demonstrators in various colours of clothing.

If we consider the people's surroundings from the perspective of gender, women seem to be depicted in a safer environment than men, for example in a peaceful street. Mixed groups are also often placed in such surroundings; only once were they depicted in an environment with tear gas. The only people depicted in surroundings of tear gas, fire, or damaged property appear to be men. People depicted amidst a police presence are mostly men; there were only three images of women (one was dancing in front of a police line, another was being arrested, and the third was running away from the police).

The activities men and women are portrayed in also differ. Women are depicted more as passive, or in creative protests (dancing or just standing, once with their hands raised, once being arrested), but they are not depicted fighting, damaging property, or speaking, even in mixed groups. These activities are in images with men only.

To sum up, there does not seem to be a great difference between Czech and British alternative media in their gender representation. But there are differences between particular publications: 'On Fire', 'Do or Die', and 'Free Labour' focus on representing 'fighting men dressed in black (often depicted on the cover or the first page), while 'We Are Everywhere' and 'A-kontra' depict women in pink, protesting creatively, on the front cover, and slightly more often, also inside the publication than the other above - mentioned magazines. 'SchNEWS' lies somewhere between these two groups.

\section{Women as fairies, men as fighters - a closer look at some images}

There are various types of protest in the anti-globalisation movement; and there are said to be two opposite tactics that are used: 'fluffy' (non-violent direct action) and 'spikey' (using violence against property and the police) [Atton 2002]. According to my research, these protests appear to be represented as gendered in the alternative media. Women symbolise the non-violent, creative, and pacifist protest - they are signs of peace, love, and beauty. In pink carnival costumes with corsets and garters they look like something between princesses and prostitutes. They are represented as vulnerable, unarmed, and unprotected people confronting the police and power. ${ }^{14}$

${ }_{13}$ This could be due to the focus of the book 'On Fire' on the protests of the Black Bloc.

${ }^{14}$ Images such as 'Frivolity on the Run' and 'Girl with a Heart', and images of women with their hands raised. 
Generally, "images of women have repeatedly signified qualities of a symbolic nature" (liberty, justice, humanity) [Macdonald 1995: 32]. The alternative media seem to create ideas about femininity ${ }^{15}$ in the anti-globalisation protest. Women play feminine roles even in violent, dangerous events, and women fighting protected under balaclavas are not depicted as heroines. Men are portrayed more as individuals, fighting against power or destroying the symbols of capitalism (banks, McDonalds).

What is associated with women suggests their inferiority and all feminine characteristics "are considered to clash with honest politics and upright citizenship and (...) can be characterized as deviations from the male norm" [Hermes 1997: 74]. This can also be traced in the protest: the 'women's' protest is colourful and creative, but it is portrayed in the media as soft and pacifistic, and not effective in confronting the police and power structures. Conversely, fighting the police is presented as important. Fighting is associated with men; the male is the norm in protest. Anti-globalisation demonstrations are represented as a kind of war in the mainstream media (the Czech media especially highlighted this aspect), and also in the alternative media. Demonstrations are presented as battles, ${ }^{16}$ and the whole movement seems to evoke notions of war. Activists are armed with sticks and stones, and protected by helmets and gas masks, while the police are armed with tanks, tear gas, and water cannons. Generally, war is very much a man's affair.

Differences can also be found in the police behaviour toward activists, distinguishable according to gender. Often, many people are arrested after the demonstrations, and when in custody the police appear to use violence against them; men report being beaten and women report being sexually harassed. The differences can be seen in the photographs representing the moment of an activist's arrest - men are beaten and kicked by the police, ${ }^{17}$ while a police officer arresting a female activist searches her and touches her breast. ${ }^{18}$ The activist killed by the police in Genoa was male, and he became a hero of the protest. According to the images, it is less probable that a woman could be killed as women participate less in the protest and in the violent fights in particular. The young man was killed after attacking police in a battle. According to the representation, if the woman were killed it would probably be in a non-violent protest, and it could then evoke a more angry reaction from the public in response to police violence.

There are also, in my view, gender differences in the representation of nudity. There is one naked male activist depicted ${ }^{19}$ yet no naked women, although female nudity is sometimes used in protest (especially anti-war protests ${ }^{20}$ ). In the Western

\footnotetext{
15 As do all the media [Macdonald 2003].

${ }^{16}$ The books make direct reference to battle in their titles: 'On Fire: The Battle of Genoa', 'The Battle of Seattle'.

17 'On Fire' (Genoa).

18 'A-kontra' (Prague).

${ }^{19}$ In Prague, ‘Do or Die' p.1.

${ }^{20}$ For example, Australian women protested against the war in Iraq in February 2003 (MFDnes, 2003).
} 
visual tradition women are usually portrayed naked or partially clad; female nudity signifies passivity, sexual allure, and spectacle [Rose 2001]. Male nudity also attracts a person's gaze, and the media thus appears to be interested in it, too. In the protests the naked body serves as a placard on which to write political slogans. The image of the naked man contrasts with that of the fully dressed man in a balaclava depicted with street fires in the background, and he appears vulnerable. Generally vulnerability is more associated with femininity. The image of the naked man, however, is not equivalent to the images of women presented; the asymmetry in this exists because "the relationships of power and control are not so easily reversible" [Pollock 1987: 46]. "In the visual tradition of the nude, men have always had privileged access to the sight of the female body" [Betterton 1987: 11]. In the protests male nudity seems comical and ironic, especially in one image of a man with a bank note on his penis. The penetration of money here seems to signify the debasement of money and capital. This is a rare image. It is not usually possible to show male genitals in the mainstream media, as such images are considered shocking and pornographic. In the alternative media, however, it is possible.

\section{Representation and reality in the anti-globalisation movement}

Although the theories of gender and representation question the relationship between representation and reality, I cannot help but see the images in this way. Given the variations between the media studied in this research, it appears that the representation in the alternative media is biased and constructed. There is no representation $^{21}$ of different masculinities (men protesting creatively or dressed in pink), femininities (older women, women fighters), union workers, or people of different age and race (there was an immigrants march in Genoa). It is possible to glimpse role-reversal in the depiction of women in the Black Bloc or White Overalls, but there are no men in pink costumes represented at all. Generally, men transgressing gender norms are less tolerated than women and in the alternative media.

The theories suggesting that representation is always constructed according to some bias seem to be validated here, even in alternative media, whose activists claim to be presenting reality without bias. ${ }^{22}$ Their truth apparently does not include everyone, and mostly the interests of men's groups are presented. ${ }^{23}$ The protest is represented as mostly a Black Bloc affair (there is one photograph of activists in balaclavas and with sticks called 'Your Humble Editors' in 'Do or Die'). That "men con-

\footnotetext{
21 But I saw them during the protests.

${ }^{22}$ The mainstream media present the protests from another point of view. They portray demonstrators as aggressive people, destroying property, and as people from whom the police need to protect us, and they do not present women and creative protest at all (at least the Czech media and some British media that I have seen do not).

${ }^{23}$ The editors behind the Czech magazines and behind 'Do or Die' consist only of men. In 'SchNEWS' and 'We Are Everywhere' there are some women involved, but fewer than men. This information is not available for 'On Fire'.
} 
trol the media through which visual images are circulated" [King 1992: 133] is a fact that appears to be reiterated even in the alternative media.

As the gender representation of the anti-globalisation movement in particular media sources is similar in many aspects (they represent fewer women and depict them in different roles than men), this would seem to relate to the reality of the antiglobalisation movement. When the Czech anti-globalisation or radical Left movement is described, there are no [Sokačová 2002] or very few women [Bastl 2001] mentioned among the activists. According to ethnographical data from research on gender in the anti-globalisation or radical Left movement in the Czech Republic [Hašková and Kolářová 2003], women do participate less than men; about 20\% of activists in the movement are women. In addition, there seems to be a gender division of the movement's activities - women are more involved in groups that are supportive and care-oriented (cooking and first aid at demonstrations). They do not participate in violent activities as much as men, and their protest seems to be more creative. Generally, women's protest is creative and non-violent and draws on cultural resources [West and Blumberg 1990: 28], while armed fighting is viewed as an exclusively male political action [Lobao 1990: 180].

Roth [2001] suggests that the gender stereotypes that exist in society as a whole are often reproduced in social movements. In revolutionary movements, "solidarity and community has meant that women are little more than auxiliaries to the comrades and that women's political demands must wait until after the revolution" [Pateman 1988: 110]. Social movements as a part of the public sphere are constructed as a male domain and are dominated by masculine principles. Women entering the social movement are expected to play a traditional female role.

\section{Conclusion}

By analysing visual images in the British and Czech alternative media I have found that these media present the protest as gendered. Women were represented less than men and depicted performing different activities than men at the demonstrations in Prague and Genoa. These findings correspond with the theories about gender representation in the mainstream media. I have focused on gender representation, but there are also other groups of protesters (of different age, ethnicity and sexuality) that are not represented in the alternative media either.

Women and men are associated with different meanings in the images I examined. The alternative media construct the notions of femininity and masculinity in protest. Women symbolise peaceful protest, whereas men are associated with confrontational tactics. Although pacifist tactics are positive in general, they are considered inferior and not effective in the struggle of the anti-globalisation movement. Fighting and damaging property is understood as more important. The whole struggle is represented as a male institution, in which women do not participate, or where they are associated with opposite meanings, such as peace, love, and non-violence. 


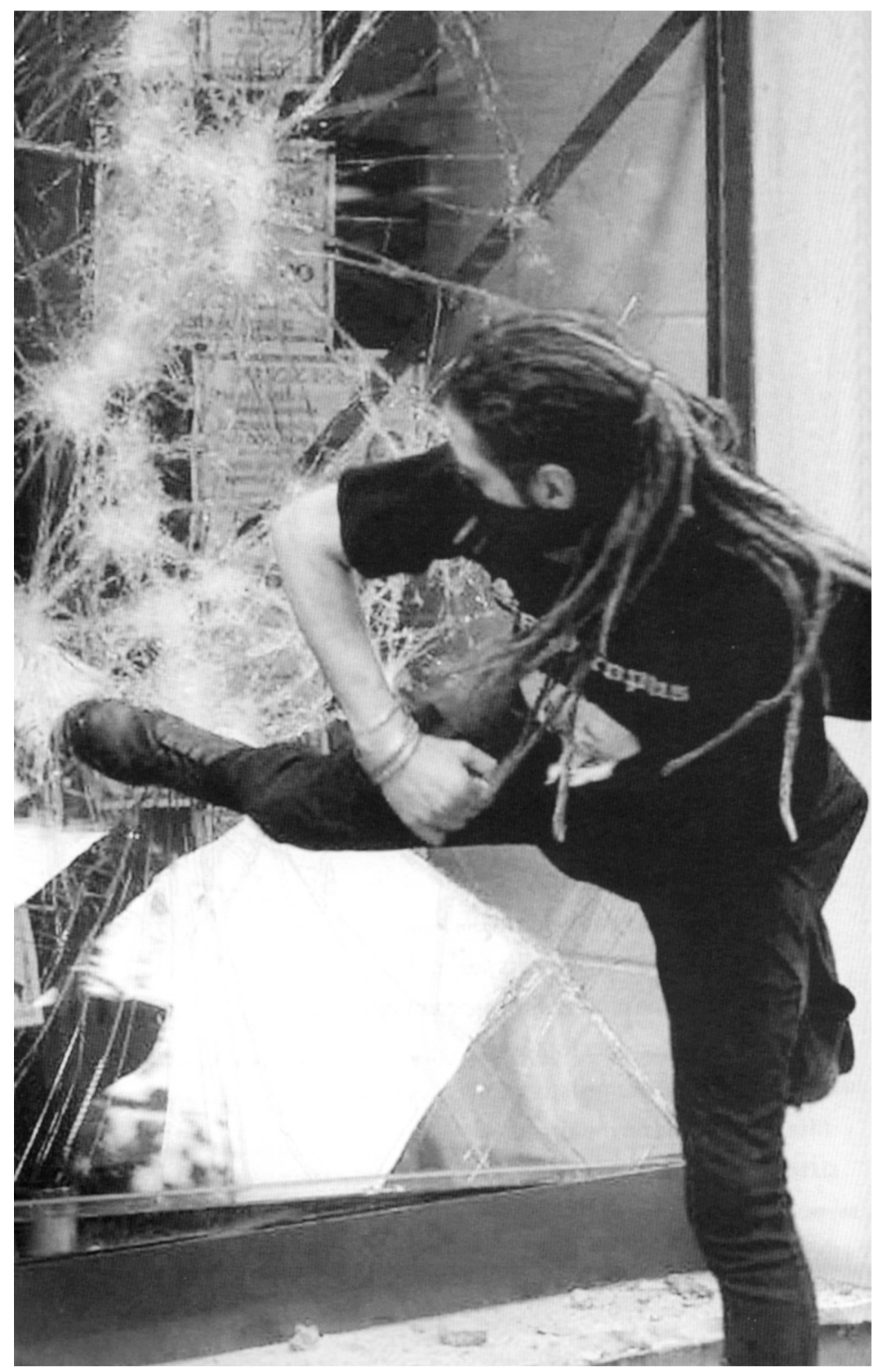

Smashing the Window (Genoa), from 'On Fire' 
The representation of the anti-globalisation movement in the alternative media seems biased toward the interests of the editorial groups behind them, which consist mainly of men and are often part of the Black Bloc at the demonstrations. Representation in general is influenced by those who control the media (in both the alternative and the mainstream media). Although theorists present the alternative media as critical of the mainstream and as a medium for the representation of marginalised groups, they acknowledge that the alternative media vary in terms of the depth of their radicalism. According to my research, they are not radical enough to present women and men in non-traditional roles.

Nevertheless, this representation of gender appears to relate to reality, because according to theories on social movements and according to Czech data, women do participate less in the anti-globalisation movement than men and do perform activities traditionally associated with femininity. It seems that stereotypical gender relations of society as a whole are reproduced in the anti-globalisation movement. Yet the gendered roles in the movement are exaggerated by the stereotypical representation of women and men. Although they try to be critical of the mainstream and endeavour to change society, the alternative media can be seen as a tool for the transmission and confirmation of gender patterns. Mohanty's claim that while women do participate in the anti-globalisation movement it remains dominated by masculine discourse seems to have been verified in my research.

The alternative media from the UK and the Czech Republic do not differ significantly, but there are slight differences between particular magazines, according to the editors' orientations. In both countries, it is possible to find some alternative media that more often show men fighting and others that more often depict nonviolent protest and women. I expected that the Czech alternative media would be less gender sensitive owing to the fact that there is less gender awareness here and feminism began developing several decades later than in the UK. Nevertheless, the Czech movement is part of the global movement, and it is also influenced by the foreign media in gender representation. The differences between the particular media sources also have something to do with who their target groups are. If the magazine or book targets a larger audience than the movement, it seems to present less violence and more women. On the other hand, when it is directed into the ranks of the movement it emphasises the activists as (male) fighters.

Future trends in the representation of men and women in the alternative media could resemble already been observed in the mainstream media: either women (and other marginalised groups) establish their own alternative media, with adequate representation, or they try to change the existing media from within and participate in the editorial groups.

MARTA Kolářová is a PhD student in sociology at the Faculty of Social Sciences, Charles University in Prague. Her doctoral dissertation focuses on globalisation and the anti-globalisation movement from a gender perspective. She studied in the gender studies programme 
at Sussex University, Brighton, UK and she is currently working in the Gender and Sociology Department at the Institute of Sociology AS CR on a research project focusing on gender aspects of education.

\section{References}

Allen, R. 1992. "Analysing Representations." Pp. 21-42 in Imagining Women: Cultural Representations and Gender, edited by F. Bonner, L. Goodman, R. Allen, L. Janes and C. King. Cambridge, Oxford: Polity Press.

Atton, C. 2002. Alternative Media. London: Sage.

Bastl, M. 2001. Radikální levice v České republice. (The Radical Left in the Czech Republic). Brno: Masarykova univerzita.

Betterton, R. (ed.) 1987. Looking On: Images of Femininity in the Visual Arts and Media. London: Pandora.

Downing, J.D.H. 2001. Radical Media: Rebellious Communication and Social Movements. London: Sage.

Geraghty, C. 1996. “Representation and Popular Culture.” Pp. 265-277 in Mass Media and Society, edited by J. Curran and M. Gurevitch. London: Arnold.

Hall, S. (ed.) 1997. Representation: Cultural Representations and Signifying Practices. London: Sage.

Hašková, H. and M. Kolářová. 2003. “Women’s Non-Governmental Organizations and Women's Groups in Left- and Right-Wing Social Movements." Pp. 26-34 in Women's Civic and Political Participation in the Czech Republic and the Role of the European Union Gender Equality and Accession Policies, edited by H. Hašková and A. Kř̌žzová. Prague: Institute of Sociology.

Hermes, J. 1997. “Gender and Media Studies: No Woman, No Cry." Pp. 65-95 in International Media Research, edited by J. Corner, P. Schlesinger and R. Silvestone. London: Routledge.

King, C. 1992. "The Politics of Representation: A Democracy of the Gaze." Pp. 131-139 in Imagining Women: Cultural Representations and Gender, edited by F. Bonner, L. Goodman, R. Allen, L. Janes and C. King. Cambridge, Oxford: Polity Press.

Lobao, L. 1990. “Women in Revolutionary Movements." Pp. 180-204 in Women and Social Protest, edited by G. West and R.L. Blumberg. Oxford: Oxford University Press.

Macdonald, M. 1995. Representing Women: Myths of Femininity in the Popular Media. London: Arnold.

Macdonald, M. 2003. Exploring Media Discourse. London: Arnold.

Mohanty, C. T. 2003. “'Under Western Eyes' Revisited: Feminist Solidarity through Anticapitalist Struggles." Signs 28 (2): 499-536.

Notes from Nowhere (ed.) 2003. We Are Everywhere: The Irresistible Rise of Global Anticapitalism. London, New York: Verso.

Pateman, C. 1988. "The Fraternal Social Contract." Pp. 101-128 in Civil Society and the State. New European Perspectives, edited by J. Keane. London: Verso.

Pollock, G. 1987. “What's Wrong with Images of Women?" Pp. 40-48 in Looking On: Images of Femininity in the Visual Arts and Media, edited by R. Betterton. London: Pandora.

Rose, G. 2001. Visual Methodologies. London: Sage.

Roth, B. 2001. "What Are Social Movements and What Is Gendered about Women's Participation in Social Movements? A Sociological Perspective." $<$ http://womhist.binghamton.edu/socm/intro.htm> (20 Dec. 2003). 
Sokačová, L. 2002. Praha 2000. Prague: FSV Univerzita Karlova.

Starr, A. 2000. Naming the Enemy: Anti-corporate Movements Confront Globalization. London: Zed books.

Waterman, P. 2001. “Gender and Globalization: Where, Now, Are the Women, the Feminists...and the Movement?" The Commoner, <www.commoner.org.uk/revwat3.htm>, (5 January 2004).

West, G. and R.L. Blumberg. 1990. “Reconstructing Social Protest from a Feminist Perspective." Pp. 3-35 in Women and Social Protest, edited by G. West and R.L. Blumberg. Oxford: Oxford University Press.

Znebejánek, F. 1997. Sociální hnutí. (Social Movements). Prague: Sociologické nakladatelství. Zoonen, van L. 1996. "Feminist Perspectives On The Media." Pp. 31-52 in Mass Media and Society, edited by J. Curran and M. Gurevitch. London: Arnold.

\section{Primary sources}

A-kontra. 7/2000, 6/2001.

DNES, <http://www.idnes.cz > 8 February 2003, 1 October 2000.

Desire for Change: Women on the Frontline of Global Resistance. 2001. London: PGA. Do or Die 9, 2000.

Notes from Nowhere (ed.). 2003. We Are Everywhere: The Irresistible Rise of Global Anticapitalism, London: Verso.

On Fire: The Battle of Genoa and the Anti-capitalist Movement. 2001. ?: One Off Press.

SchNEWS, SQUALL Yearbook 2001.

SchNEWS, Yearbook 2002.

Svobodná práce (Free Labour) 18 October 2000.

Yuen, E., G. Katsiaficas, D. B. Rose 2002. The Battle of Seattle. New York: Soft Skull Press. 